\title{
Child Marriage in Rural Bangladesh and Its Consequences on Reproductive and Maternal Health: An Empirical Study
}

\author{
Samira Salam ${ }^{1}$ and Bipasha Aktar ${ }^{2}$ \\ ${ }^{1}$ Department of Basic Science, Primeasia University, Banani, Dhaka, Bangladesh; and ${ }^{2}$ Department of Statistics, \\ Jahangirnagar University, Savar, Dhaka, Bangladesh. \\ *Correspondence: samirasalam93@gmail.com (Samira Salam, Lecturer, Department of Basic Science, Primeasia University, \\ Banani, Dhaka, Bangladesh).
}

\begin{abstract}
Despite the high prevalence of child marriage in Bangladesh and the potential adverse effects of child marriage on reproductive and maternal health outcomes, there is relatively little empirical evidence available on this issue, which has impeded efforts to stop child marriage and to initiate improved and effective adolescent health programs. The purpose of this study is to determine the causes of child marriage and its consequences on the reproductive and maternal health of child brides in Bangladesh. Data for the study came from a cross-sectional sample survey and the ultimate sampling units were selected by using a three-stage cluster sampling technique. The results of the study suggest that the dominant driving factors for child marriage are: poverty, lack of education, social and cultural norms, ensuring daughters' financial security, protection of daughters from sexual harassment and unwelcome sexual advances. There are serious consequences of child marriage on adolescents' health. It truncates a girl's childhood, gives rise to severe physical and psychological risks on health, and takes her from internationally accepted human rights. The difference between mean years of marriage and first birth interval indicates that Bangladeshi adolescents hurry to initiate childbearing. They are at high risk of reproductive health. Most of them suffered from various maternal health problems such as gynecological problems before pregnancy, complications during pregnancy, at the time of delivery, and after delivery due to the absence of proper maturity. Child marriage enlarges boundary of vulnerability to adolescents that leads to poor fertility control and fertility-related outcomes, and poor maternal health care issues.
\end{abstract}

Keywords: Child marriage, Reproductive health, Contraceptive use, Domestic violence, and Bangladesh.

\section{INTRODUCTION:}

Child marriage, defined by UNICEF as marriage prior to age 18 years, is a reality for over 60million women worldwide (Nour, 2009). Despite international agreements and national laws, marriage of girls aged below 18 is common worldwide. The latest international estimates indicate that worldwide $5 \%$ of the women among aged 20-24 married before they reached at age 15 and $21 \%$ married before they reached age of 18 (UNICEF, 2019). However, the extent of child marriage varies substantially between regions/ countries; the highest rates are found in West and Central Africa (40\%), followed by South Asia (30\%), Latin America and Caribbean (25\%) and Middle East and North Africa (18\%) (UNICEF, 2019). 
In Bangladesh, about 59\% of women aged 20-24 married before they reach of age 18 (UNICEF, 2019). National and international communities are increasingly recognized child marriage as a human rights violation that prevents girls from obtaining an education, enjoying optimal health, maturing, and ultimately choosing their own life partners (Mathur et al., 2003; UNICEF, 2005; Save the Children, 2004; Montazeri et al., 2016). This practice has serious consequences for national development, stunting the educational and vocational opportunities for a large sector of the population (Mahato et al., 2016).

The lack of facilities for health, education, physical protection, and independent status deprives girls of their basic human rights, and it also acts like a brake to socioeconomic development. In fact, child marriage undercuts the accomplishment of each of the eight Millennium Development Goals and global targets to bring down poverty rate worldwide (Hervish \& Feldman-Jacobs, 2011; UNICEF, 2006; IPPF, 2007, Kalamar et al., 2016). Marriage at a very young age has severe consequences on health for both child brides and their children. The effects of child marriage to the girls who experience it can be shattering (Jain \& Kurz, 2007; Mathur et al., 2003). Child marriage steers to early childbearing who cans results significantly higher maternal mortality and morbidity rates as well as higher infant mortality rates (Mensch, 2005; UNICEF, 2005; Save the Children, 2004).

Recognizing the awful consequences of child marriage, the United Nations and other international agencies have attempted to stop child marriage since 1948. The 2030 Agenda for Sustainable Development's Goal for Gender Equality (SDG5 to: Achieve Gender Equality and Empower all Women and Girls) fixes a number of ambitious goals that will measure advancement towards achieving this goal. One of such goals is to remove all harmful practices, such as child marriage and female genital mutilation. In this regard, the UN Committee on Elimination of Discrimination against Women (CEDAW) declared the right to protect adolescent from early marriage in article 16 stating, "The betrothal and marriage of a child shall have no legal effect, and all necessary action including legislation, shall be taken to specify a minimum age

UniversePG I www.universepg.com for marriage" (UN CEDAW, 1994). Child marriage was also identified by the Pan African Forum against Sexual Exploitation of Child (Mikhail, 2010).

At the national level, efforts to focus child marriage date back to the 1920s. For example, India attempt to end child marriage through the first legislative passage of the "Sarda Act" in 1929 (Mukherjee, 2006). Recently, legal reform lunched to gain ground in the 1970s and 1980s, as many countries like India, Bangladesh and Indonesia set the legal minimum age of marriage for girls to 18 . At the same time, some human rights activists and the United Nations initiated efforts to stop harmful traditional practices affecting women (Yasmin and Husna, 2020). However, programmatic interventions to eliminated child marriage have only gained motion since the 1990s, coinciding with the attention to adolescent maternal health at the Cairo International Conference on Population and Development in 1994 and the affirmation of women's and girls' human rights at the UN International Conference on Women in Beijing in 1995 (UNICEF, 2001).

In many countries, the legal age for marriage is 18 , yet some governments enforce these laws loosely. For example, the percentage of girls married before age 18 in Niger is $77 \%$, in Chad $71 \%$, in Mali $63 \%$, in Cameroon 61\%, and in Mozambique 57\% (UNICEF, 2019). In parts of Ethiopia, $50 \%$ of girls are married before the age of 15, and in Mali, 39\% (UNICEF, 2019).

Despite the pervasiveness and severe consequences ascribed to the practice of child marriage, little empirical research has been published in the past decade on this issue or the related public health consequences, creating a critical gap hindering the work of both practitioners and policy makers. Bangladesh, one of the fast-growing developing countries within South Asia, has maintained laws against child marriage since 1984 (Kamal, 2012), child marriage has still remained a serious problem in Bangladesh and has not received sufficient attention by researchers. Therefore, it is very much essential to carry out research for clear understanding of the factors of child marriage from child brides' own perspectives and its consequences on reproductive 
health. It will contribute to designing and developing culturally responsive interventions and improving the health programs for these girls. Given the importance of child marriage and its impacts on reproductive health of child mothers in Bangladesh, this quantitative study was carried out to explore determinants of child marriage from child brides' own perspectives in Bangladesh setting. Therefore, the main purpose of this study was to determine the causes and consequences of child marriage in Bangladesh based on the deeper understanding from the intensive interviews of child brides in Bangladesh.

\section{METHODOLOGY:}

A quantitative type of research method was used to collect the data from the informants on child marriage. Information was collected from ever married women who married before reaching age of 18 years and who experienced at least two years of conjugal lives. Data for this study were collected from a sample survey conducted in two villages of Bangladesh. The sample was obtained by using three-stage cluster sampling. In the first stage, a district from the 64 districts of Bangladesh was randomly selected-the selected district was Jhenaidah. In the second stage, two unions were randomly selected from the selected district.

The selected unions were Kumrabaria and Paglakhanai. In the third stage, two villages, one from each selected union were selected randomly. The selected villages were Defolbari and Korapara. All the ever-married women who married before reaching age 18 and experienced least two years of marital life were interviewed by a structured questionnaire. These procedures resulted in a sample of 80 brides: 50 from Defolbari and 30 from Korapara.

\section{RESULTS AND DISCUSSION:}

\section{Background Characteristics of the Respondents -} Majority of the respondents (65.2\%) were in the age cohort 20-24 and had little exposure to formal education as $3.8 \%$ were illiterate and $45 \%$ were attended up to primary school while $23.8 \%$ were attended and completed secondary school education. The maximum level of education of brides was secondary school certificate (SSC), which can be completed before reaching age 18 years. After the UniversePG I www.universepg.com marriage, a girl has to do the role of a wife, a domestic worker, as well as a mother at her husband's household. Thus, the practice of child marriage is directly impacting educational opportunities of girls. Once girls' get married, they consciously being denied from the formal educational setting and started to take care of their in-laws at home and producing children.

Research results showed that child marriage resulted in removal from school or limited access to educational opportunities completing up to the level of secondary school certificate. It is seen from the Table 1 that about $4 \%$ of the husbands were aged below 25 years, about $22.5 \%$ of the husbands were in the 25-29 years age cohort, about $50 \%$ of the husbands were in the 30 35yearsage cohort. Majority of the brides (about 45\%) were engaged in household works, handicrafts $(17.5 \%)$, salaried works $(27.6 \%)$, and day labor $(8.8 \%)$.

Regarding the husbands' occupation, major occupations were farming (25\%), service (24\%) and pity business (21\%). Estimated incomes of brides revealed that most of the brides (45\%) had no cash income, about 30\% had less than BDT 4,000 per month and only $9 \%$ had BDT 10,000 or more income per month. On the other hand, majority (40\%) of the husbands had <BDT 10,000, about 30\% had BDT $10,000 \sim 13,999$ and only $5 \%$ had BDT 20,000 or more income per month.

Table 1: Background characteristics of the respondents.

\begin{tabular}{|l|c|}
\hline Characteristics & Percent \\
\hline \multicolumn{2}{|l|}{ Age of the respondent } \\
\hline$<20$ & 3.8 \\
\hline $20-24$ & 65.2 \\
\hline $25 \sim 29$ & 31.0 \\
\hline Age of the husband & 3.8 \\
\hline$<25$ & 22.5 \\
\hline $25 \sim 29$ & 50.0 \\
\hline $30 \sim 34$ & 23.7 \\
\hline $35 \sim 39$ & 3.8 \\
\hline Educational qualification of the respondent \\
\hline Illiterate \\
\hline
\end{tabular}




\begin{tabular}{|c|c|}
\hline Primary (Class I-V) & 45.0 \\
\hline Secondary (Class VI-IX) & 17.5 \\
\hline Secondary School Certificate (S.S.C.) & 23.8 \\
\hline Higher Secondary Certificate (H.S.C.) & 10.0 \\
\hline \multicolumn{2}{|l|}{ Educational of the husband } \\
\hline Illiterate & 0.0 \\
\hline Primary (Class I-V) & 26.3 \\
\hline Secondary (Class VI-IX) & 17.5 \\
\hline Secondary School Certificate (S.S.C.) & 30.0 \\
\hline Higher Secondary Certificate (H.S.C.) & 26.3 \\
\hline \multicolumn{2}{|l|}{ Occupation of the respondent } \\
\hline Housewife & 45.0 \\
\hline Salaried workers & 27.6 \\
\hline Hand workers & 17.5 \\
\hline Day laborer & 8.8 \\
\hline Others & 1.1 \\
\hline \multicolumn{2}{|l|}{ Occupation of the husband } \\
\hline Agriculture & 25.0 \\
\hline Day laborer & 13.8 \\
\hline Service & 23.8 \\
\hline Business & 21.3 \\
\hline Others & 16.3 \\
\hline \multicolumn{2}{|c|}{ Monthly income (in BDT*) of the respondent } \\
\hline House wife (no cash income) & 45.0 \\
\hline$<4000$ & 30.0 \\
\hline $4000 \sim 5999$ & 8.8 \\
\hline $6000 \sim 7999$ & 5.0 \\
\hline 8000 9999 & 2.3 \\
\hline 10000 and more & 9.0 \\
\hline \multicolumn{2}{|l|}{ Husband's monthly income (in BDT*) } \\
\hline$<10,000$ & 40.0 \\
\hline $10,000 \sim 13,999$ & 27.5 \\
\hline $14,000 \sim 16,999$ & 15.0 \\
\hline $17,000 \sim 19,999$ & 12.5 \\
\hline 20,000 and more & 5.0 \\
\hline
\end{tabular}

between these two proportions is significant. Occupation of about $39 \%$ of the fathers of child brides was farming and about $61 \%$ of the fathers' occupation was non-farming and the difference between these two proportions is statistically significant.

Monthly income of about $88 \%$ of the fathers of child bride was <BDT 10,000 and about $39 \%$ of the fathers of child was more than BDT 10,000 and difference of these two proportions is statistically highly significant. Monthly family income of majority of families (51\%) was not sufficient to maintain the family and it was sufficient of $49 \%$ of the families.

Economic condition of the households at the time of marriage was not good of about $75 \%$ of the child brides and the difference between the proportions of economic conditions is statistically highly significant. About $51 \%$ of the child brides did not know about legal age of marriage. Results of the study indicate that child marriage is more likely to occur in the life of girls who live in such a household setting in which household head is less educated, father's occupation is other than agriculture, monthly family income is less than BDT 10,000, and live in poverty.

Birth, marriage and death are the trio of key events in most people's lives. But only one - is a matter of choice. The right to exercise that choice was recognized as a principle of law and has long been established in international human rights instruments. Yet many girls, especially in case of child marriage, enter marriage without any chance of exercising their rights to choose. In the study area, about $21 \%$ of the child marriages occurred where parents did not seek child brides' consents. In some cases, girls are forced into marriage. In other cases, girls are simply too young to make an informed decision to choose their marriage partner or about the effects of marriage itself. What they pass for consent in the eyes of custom or the law is, in reality, not consent, consent for marriage in practice has been made by others on behalf of them. But the 1948 Universal Declaration of Human Rights (UDHR) well recognized the right to free and full consent to a marriage and in practice that consent cannot be free and full when at least one partner is very immature. 
Table 2: Socioeconomic characteristics of the parents of brides.

\begin{tabular}{|c|c|c|}
\hline Characteristics & Percent & p-value \\
\hline \multicolumn{3}{|c|}{ Educational Qualification of Father } \\
\hline$\leq$ Class V & 73.8 & \multirow[t]{2}{*}{0.000} \\
\hline$>$ Class V & 26.2 & \\
\hline \multicolumn{3}{|c|}{ Occupation of father at the time of marriage } \\
\hline Agriculture & 38.8 & \multirow[t]{2}{*}{0.0227} \\
\hline Others & 61.2 & \\
\hline \multicolumn{3}{|c|}{ Monthly income of father at the time of marriage } \\
\hline$<$ BDT 10,000 & 87.5 & \multirow[t]{2}{*}{.0000} \\
\hline BDT 10,000 or more & 12.5 & \\
\hline \multicolumn{3}{|c|}{ Whether fathers' income was sufficient to maintain family needs } \\
\hline Yes & 48.8 & \multirow[t]{2}{*}{0.4168} \\
\hline No & 51.2 & \\
\hline \multicolumn{3}{|c|}{ Economic condition of the family at the time of marriage } \\
\hline Good & 25 & \multirow[t]{2}{*}{0.0000} \\
\hline Not good & 75 & \\
\hline \multicolumn{3}{|c|}{ Whether knew legal age of marriage at the time of marriage } \\
\hline Knew & 48.8 & \multirow[t]{2}{*}{0.4168} \\
\hline Did not know & 51.2 & \\
\hline \multicolumn{3}{|c|}{ Whether seek her consent for marriage } \\
\hline Yes & 78.8 & \multirow[t]{2}{*}{0.0000} \\
\hline No & 21.2 & \\
\hline
\end{tabular}

p-value is based on Z-statistic

Age of brides and grooms at the time of marriage Many girls, especially in case of child marriage, enter marriage without any chance of exercising their rights to make decision about time when to marriage. Customs surrounding marriage, including the desirable age and the way in which a spouse is selected, depend on a society's view of the family-its role, structure, pattern of life, and individual and collective responsibilities of its members. Stereotypical views of women's role in society further contribute to the acceptability and pervasiveness of child marriage: an age gap between husbands and wives can secure male dominance in the household and younger brides are regarded as more obedient and respectful of their husbands. It is evident from Table 3 that about $24 \%$ of the child brides got married before they reached at age 15 and about $76 \%$ got married when they reached at age 15-17.

The mean age of child bride at marriage was 15.6 years $(\mathrm{SD}=1.4$ years), the minimum age of child bride at marriage was 12 years and the maximum age of child bride at marriage was 17 years. On the other hand, about $2.5 \%$ of the grooms got married before they reached age 15 and about $58 \%$ of the grooms got married at the age of 21 24. The mean age of grooms at the time of marriage was 21.6 years $(\mathrm{SD}=2.77$ years), the minimum age of grooms at marriage was 14 years and maximum age of grooms at marriage was 29 years. The difference of mean age of brides and grooms at the time of marriage is statistically significant.

Table 3: Percent distribution of respondents according to age at first marriage.

\begin{tabular}{|l|c|}
\hline Age at the time of marriage & Percent \\
\hline Age at marriage of girls & \\
\hline$<15$ & 23.8 \\
\hline $15 \sim 17$ & 76.2 \\
\hline Minimum & 12.0 \\
\hline Maximum & 17.0 \\
\hline
\end{tabular}




\begin{tabular}{|c|c|}
\hline Mean \pm Standard Deviation & $15.6 \pm 1.4$ \\
\hline \multicolumn{2}{|l|}{ Age at marriage of husband } \\
\hline$<15$ & 2.5 \\
\hline $15 \sim 17$ & 2.6 \\
\hline $18 \sim 20$ & 23.8 \\
\hline $21 \sim 24$ & 57.7 \\
\hline $25 \sim 29$ & 13.4 \\
\hline Minimum & 14.0 \\
\hline Maximum & 29.0 \\
\hline Mean \pm Standard Deviation & $21.6 \pm 2.77$ \\
\hline $\begin{array}{l}\text { Difference between mean age at } \\
\text { marriage of husband and wife }\end{array}$ & $\begin{array}{c}\mathrm{Z}=17.29 \\
\mathrm{p} \text {-value }=0.000\end{array}$ \\
\hline
\end{tabular}

Reasons for coercing child marriage - Nour, (2009) highlighted that there were major three forces those drive child marriages i.e. poverty, the need to reinforce social ties and the belief that it offers protection as well as parents have to ensure the financial security of their daughters and have to reduce the economic burden on the family due to daughter. Girls are costly to feed, clothe, and educate, and they eventually leave the household. Thus, poor families want to reduce the number of children to feed, clothe and educate. Child marriage is being used as a strategy to throw the economic burden for their care to others. Poverty plays a central role in perpetuating child marriage. Where poverty is acute, a young girl may be regarded as an economic burden and girls are married early to provide protection, security and support of a male guardian. All these notions are supported by the results of this study. It is seen from Table 4 that about $55 \%$ of the child marriages occurred because of reducing the economic burden of the family and about $52 \%$ of the child marriages occurred because of financial security of the daughters.

Social norms on the control of female sexuality have a significant impact on child marriage. There was a common belief among the parents that marrying the daughters young should protect them from rape, premarital sexual activity, unintended pregnancies, which would be equally disgraceful (Nour, 2009). Whenever the incidence of rape, trafficking, domestic violence, sexual servitude, and child abduction is rising, child marriage is being used as a strategy to protect girls from sexual exposure. Parents feel that their daughters will remain safe if they got married and remain in the husbands' households. In the study area, about $46 \%$ of the child marriages occurred to protect daughters from unwelcome sexual advances. About $39 \%$ of the parents believed that husband's house was the safer place for their daughters. Parents also feel proud in the society by marrying their daughter to a "good" family in terms of social status. By marrying their daughters to a good family, parents establish social ties between powerful families and improve their social status. Moreover, they look upon marriage as a family-building strategy. Parents used to arrange the child marriage as means of uniting two families. About $39 \%$ of the parents arranged marriage for their daughters as a family-building strategy.

Table 4: Reasons of child marriage.

\begin{tabular}{|l|c|}
\hline Reason & Percent* \\
\hline To ensure daughter's financial security & 51.9 \\
\hline $\begin{array}{l}\text { To protect daughters from unwelcome } \\
\text { sexual advances }\end{array}$ & 45.6 \\
\hline $\begin{array}{l}\text { To reduce the economic burden of the } \\
\text { family }\end{array}$ & 55.7 \\
\hline To ensure safer place for daughter & 40.5 \\
\hline To use as a family-building strategy & 39.2 \\
\hline Others & 7.6 \\
\hline
\end{tabular}

* Total percentage is not 100 because of multiple responses.

\section{Consequences of Child Marriage on Reproductive Health}

\section{Age of Child Brides at the Time of First Birth and} Gap Between First Birth and Marriage - If girls marry men outside their village, they must move away. Coping with the unknown indoor and outdoor of home creates an intensely lonely and isolated life for them. As these girls' consider their new roles as wives and mothers, they also take over the primary job of domestic worker at their husband's house hold (Nour, 2009). Husbands are usually much older than the girls and thus have little in common with them and their new brides are expected to reproduce. Girls often embrace their fate and give birth quickly to secure their identity, status, and respect as an adult. Thus, deliveries from child marriage are "too soon, too close, too many, or too late" (Marriage and the Family, 2009). Child marriage force adolescents into parenthood and frequently motherhood before they are 
psychologically and physically mature. It also deprives girls of the capacity to practice choice. The results of the study indicate that about $31 \%$ of the child brides gave first birth within 12 months of their marriage and about $45 \%$ of the child brides gave first birth within 12-24 months of marriage. The average gap of marriage and the first birth was 2.16 years (with $\mathrm{SD}=$ 1.1 years). This means that Bangladeshi adolescents hurry to initiate child bearing soon after marriage. Social pressure as well as the inferior status of women in Bangladeshi society leads women to try to conceive shortly after having married. The highest health risk is during their first pregnancy (Nour, 2009).

Studies indicate that the younger the age at sexual intercourse and first pregnancy, the higher the incidence of HIV infection (ICRW, 2005). Child marriage exposes young brides to early and forced pregnancies which increases the risk of maternal and infant morbidity and mortality (UN Human Rights Council, 2014). It puts girls at greater risk of obstetric fistula and sexually transmitted diseases, including HIV/AIDS, as their husbands are usually much older. Results of the study indicate that about $3 \%$ of the brides gave first birth before they reached at age 15 and $41 \%$ of the brides gave first birth when they reached at age 15 17. Average age of giving first birth was 17.7 years (with $\mathrm{SD}=2.6$ years).

Girls aged 10 to 15 years have small pelvises and are not ready for childbearing. As a result, they face significant risks during pregnancy, including obstetric fistula and death. Girls aged 10 to 14 years are five times more likely to die than women aged 20 to 24 during pregnancy and at the time of child birth (UNFPA, 2007). Child marriage has intense intellectual, physical, psychological and emotional impacts and stopping chance of personal growth. It is almost certain that the outcome of child marriage will premature pregnancy and childbearing, and is likely to initiate a lifetime domestic and sexual subservience over which they have no control.

Maternal Health Care - Child marriage influences initiation of sexual activity at an age when girls' bodies are still developing and when they have little knowledge about their bodies, their sexual and reproductive health, and their right to access UniversePG I www.universepg.com contraception. As a result, child brides may face gynecological problems after initiation of sexual activity. The results of the study revealed that about $62 \%$ of the child brides had been faced gynecological problems after marriage. Among them about 23\% did not consult with doctors for their problems and about $36 \%$ did not get any help from their in-laws' family members (Table 6).

Table 5: Time span from marriage to first birth and the age at the time of fist birth.

\begin{tabular}{|c|c|}
\hline Time span of first birth & Percent \\
\hline \multicolumn{2}{|c|}{ Duration of marriage and first birth } \\
\hline 1 year & 31.3 \\
\hline 2 years & 45.0 \\
\hline 3 years & 6.3 \\
\hline 4 years & 11.3 \\
\hline 5 years & 6.3 \\
\hline Average \pm Standard deviation & $2.16 \pm 1.1$ \\
\hline \multicolumn{2}{|l|}{ Age at first birth } \\
\hline$<15$ years & 2.9 \\
\hline $15 \sim 17$ & 41.1 \\
\hline 18 20 & 46.0 \\
\hline$>20$ & 10.0 \\
\hline Minimum & 13.0 \\
\hline Maximum & 22.0 \\
\hline Average \pm Standard deviation & $17.9 \pm 1.8$ \\
\hline
\end{tabular}

Girls below the age of 18 have small pelvises and they are not ready for childbearing. So, child brides often experience pregnancies before they are physically, physiologically and emotionally ready, and they face significant barriers to accessing comprehensive and respectful medical care during pregnancy and childbirth. All these put adolescent girls at greater risk for complications during gestation and delivery. It is revealed from the study that $69 \%$ of the child brides experienced at least one serious pregnancy or birthrelated health problem which includes excessive bleeding during labor (19.0\%), obstructed and/or prolonged labor $(49.0 \%)$, frequent miscarriages $(12.0 \%)$ and prolonged sickness after childbirth (28\%) as shown in Table 6.

The study results indicate that morbidity rate is higher among young mothers and it may happen due to their 
poor nutrition, physical and emotional immaturity, and lack of access to social and reproductive services. The risks of early pregnancy and childbirth are well documented: increased risk of dying, increased risk of premature labor, complications during delivery, low birth-weight, and a higher chance that the newborn will not survive (Senderowitz, 1995).

The notion of good reproductive health covers all aspects of the reproduction process-including a satisfying and safe experience of sexual relations, the capability to reproduce, and the freedom to decide if and when to bear child. The right not to engage in sexual relations and the right to exercise control over reproduction may both be violated by child marriage. On the other side, child brides are often under intense pressure from in-law's family to give birth soon after marriage, which makes them more likely to experience early and frequent pregnancies. Proper use of contraceptive allows a couple to enjoy a sexual relationship without worry of an unwanted pregnancy and makes sure enough freedom to have children when desired (Lule et al., 2007).

We investigated fertility control before first birth in order to spacing between pregnancies and marriage to reach adulthood. The results of the study revealed that child brides were less likely to have used any fertility control methods before the first birth (48\%) as seen in Table 6. Low fertility control may account for negative fertility outcomes, such as pregnancy termination and unwanted pregnancy. Despite their significant need for maternal health services, child brides were often isolated, hard to reach, and are often unaware that such services are available (27\%), very child brides had access to contraception; nor would delayed pregnancy necessarily be acceptable to many husbands and in-laws (49\%), and they did not use contraception because of their husbands' opposition $(51 \%)$.

These results imply that child marriage denies girls the right to make fundamental decisions about their own intention to control birth. Being married early, child brides have limited ability to negotiate their sexual and reproductive health needs, including whether and when to have sex and whether and when to use contraceptive methods to control their births.

Due to physical immaturity where the pelvis and birth canal are not fully developed, child mothers often endure very prolonged/obstructed labor mainly during their first birth and become victims of morbidities like obstetric fistula (Cook et al., 2004; Ahmed, 2015). Child brides who give birth before 15 have $88 \%$ risk of developing fistula (Ahmed, 2015). Fistula patients are usually young girls who come from a socially disadvantaged group with little access to Emergency Obstetric Care, which is common in rural Bangladesh. Sometimes fragments of the placenta remain in the uterus and this may cause perineal pain. The study result revealed that, about $29 \%$ of the girls experienced fistula and $23 \%$ experienced perineal pain after their first birth (Table 6).

After child birth, mothers can often feel overwhelmed with responsibilities. This leads to anxiety and feelings of anger which easily constitute to postpartum depression, which is common with first time mothers. Due to allergens and hormonal changes during postpartum period, the immune system reacts releasing histamine into the bloodstream which causes itchy red rashes that are referred to as postpartum hives. About $28 \%$ of the girls experienced postpartum hives, vaginal discharge (26\%), uterus infection (47\%) and pronged sickness after birth (28\%) after giving the first birth. These results imply that the risk of child mothers to birth related morbidity after giving first birth is high. According to $73 \%$ of the child brides, risk to maternal health is high for giving birth during adolescent and according to $56 \%$ of the child brides; the risk to infant mortality is high for giving births during adolescent.

Pregnant women have unique and increased vulnerabilities to greater morbidity and mortality from a variety of bacterial and viral vaccine-preventable diseases. Vaccination of pregnant women cans safe guard mother against vaccine-preventable infections. A pregnant woman should get vaccinated against whooping cough and flu during each pregnancy to protect herself and her baby, with immunity for the first few months of life. But $16 \%$ of the girls did not vaccinated during the first pregnancy. 
Table 6: Percent distribution of respondents according health problems.

\begin{tabular}{|c|c|}
\hline Particulars to health problems & Percent* \\
\hline \multicolumn{2}{|l|}{ Whether faced any gynecological problems after marriage } \\
\hline Yes & 62.0 \\
\hline No & 38.0 \\
\hline \multicolumn{2}{|l|}{ Whether went to doctors for treatment } \\
\hline Yes & 77.6 \\
\hline No & 22.4 \\
\hline \multicolumn{2}{|l|}{ Whether members of in-law's family helped for treatment } \\
\hline Yes & 64.3 \\
\hline No & 35.7 \\
\hline \multicolumn{2}{|l|}{ Whether used family planning methods before first time pregnancy } \\
\hline Yes & 47.5 \\
\hline No & 52.5 \\
\hline \multicolumn{2}{|l|}{ Reasons of not using family planning methods } \\
\hline Husband and in-laws wanted child early & 48.7 \\
\hline Husband opposed to use FP methods & 51.2 \\
\hline Unaware about necessity and availability of such services & 26.8 \\
\hline Others & 2.4 \\
\hline \multicolumn{2}{|l|}{ Whether under pressure for taking birth } \\
\hline \multicolumn{2}{|l|}{ Ever Experienced pregnancy-related complications } \\
\hline Yes & 82.0 \\
\hline No & 18.0 \\
\hline \multicolumn{2}{|l|}{ Types of Complication Experienced } \\
\hline Excessive Bleeding & 19.0 \\
\hline Frequent Miscarriages & 12.0 \\
\hline Obstructed or prolonged labor & 49.0 \\
\hline Water breaking early & 53.8 \\
\hline Perineal tears & 25.0 \\
\hline \multicolumn{2}{|l|}{ Ever Experienced problems after giving first birth } \\
\hline Yes & 77.5 \\
\hline No & 22.5 \\
\hline \multicolumn{2}{|l|}{ Types of problems } \\
\hline Perineal pain & 23.0 \\
\hline Fistula & 29.0 \\
\hline Uterus infection & 47.5 \\
\hline Postpartum hives & 27.6 \\
\hline Vaginal discharge & 26.2 \\
\hline Excessive bleeding after delivery & 13.1 \\
\hline Prolonged sickness after birth & 28.0 \\
\hline \multicolumn{2}{|l|}{ Opinion on early births } \\
\hline Higher risk to maternal health & 73.3 \\
\hline Higher risk to infant mortality & 57.6 \\
\hline \multicolumn{2}{|l|}{ Whether used vaccine during pregnancy } \\
\hline Yes & 83.8 \\
\hline No & 16.3 \\
\hline
\end{tabular}

* Total percent is not 100 because of multiple responses. 
Experience of Domestic Violence - Child marriage is closely associated with intimate partner violence (Klugman et al., 2014). Age gaps between husband and wife can disempower wife, and findings from a number of countries suggest that having a much older partner can increase the risk of intimate partner violence (Klugman et al., 2014). Many of the victims of this practice suffered from prolonged domestic violence, but felt unable to leave the marriage because of economic pressures, lack of family support and other social circumstances (Klugman et al., 2014). The study results indicate that about $75 \%$ of the married adolescent's experienced intimate partner violence. Among them, 62\% experienced physical violence, and $71 \%$ experienced psychological violence from intimate partners indicating that child brides in Bangladesh are at high risk to intimate partner violence. These brides are often unable to effectively negotiate safe sex, leaving them vulnerable to sexually transmitted infections, including HIV, and early pregnancy (McFarlane, Judith et al., 2016).

Table 7: Percent distribution of respondents by domestic violence.

\begin{tabular}{|l|c|}
\hline Particulars of domestic violence & Percent \\
\hline $\begin{array}{l}\text { Whether experienced domestic violence from intimate } \\
\text { partner }\end{array}$ \\
\hline Yes & 74.7 \\
\hline No & 25.3 \\
\hline Nature of domestic violence \\
\hline Physical & 61.7 \\
\hline Phycological & 71.4 \\
\hline Sexual & 55.0 \\
\hline
\end{tabular}

\section{CONCLUSION:}

The incidence of child marriage is really one of the serious and important issues regarding the child protection because still it is happening in Bangladesh. It is also alarming us because the incidence of child marriage is highest (59\%) in Bangladesh while comparing with South Asian countries. Poverty, lack of education, social and cultural norms, protection of daughters from sexual harassments and the prevalence of unwelcome sexual advances all influence the likelihood of a girl being married before turning 18 or even earlier. The outcomes of child marriages are horrible for girls in terms of their reproductive health UniversePG I www.universepg.com and education rights because most of the girls' dropout from school after getting marriage. It truncates a girl's childhood, causes severe physical and mental health risks, and takes her from internationally accepted human rights.

The difference between mean years of marriage and first birth interval indicates that Bangladeshi adolescent's hurry to initiate childbearing soon after marriage. They are at high risk of reproductive health. Most of them suffered from various gynecological problems after marriage experienced various complications during pregnancy, at the time of delivery and after delivery due to absence of proper maturity. The uptake of opportunities for antenatal and post-natal care was reportedly low among women due to husband's attitude and ignorance. A high proportion of child brides also experienced intimate partner violence. These brides are often unable to commendably negotiate safe sex, leaving them at risk to sexually transmitted diseases like HIV and early pregnancy. Therefore, time comes now to start the campaign to stop child marriage with strong implementation of laws.

To end child marriage needs a comprehensive approach focused on the girls, their families, the community, and the government. Governmental and nongovernmental policies aimed at educating the community, raising awareness, engaging local and religious leaders, involving parents, and empowering girls through education and employment can help stop child marriage. Hence, to minimize the incidence of child marriage, government of Bangladesh has already started special programs like girl's free education, separate sanitation facilities for girls in school, child protection, and stipend for female students, child marriage protest program, empowerment of girl program and many others.

\section{ACKNOWLEDGEMENTS:}

The authors would like to thank Dr. Md. Abdus Salam, Professor, Department of Statistics, Jahangirnagar University, Savar, Dhaka for his valuable suggestions in writing this article. The authors would also like to thank the students of the Department of Statistics, Jahangirnagar University, who helped to collect data for this study. 


\section{CONFLICT OF INTERESTS:}

The authors declare no conflict of interest.

\section{REFERENCES:}

1. Ahmed, T. (2015). 'Child Marriage: A Discussion Paper', Bangladesh Journal of Bioethics, 6(2), 8-14. https://doi.org/10.3329/bioethics.v6i2.25740

2. Cook, R.J., Bernard, M.D., and Syed, S. (2004). 'Obstetric Fistula: The Challenge to Human Rights', International Journal of Gynecology and Obstetrics, 87, 72-77. https://doi.org/10.1016/j.ijgo.2004.07.005

3. Hervish, A \& Feldman-Jacobs, C. (2011). 'Who Speaks For Me? Ending Child Marriage. Policy Brief', Washington, DC: Population Reference Bureau. https://www.prb.org/wpcontent/uploads/2013/11/ending-child-marria ge.pdf

4. ICRW, (2005). 'Development Initiative on Supporting Healthy Adolescents (DISHA) project: Analysis of quantitative baseline survey data conducted in 2004', Washington, DC: ICRW.

5. IPPF, (2007). 'Ending child marriage: A guide for global policy action', International Planned Parenthood Federation and Forum on Marriage and the Rights of Women and Girls, London: IPPF.

https://www.ippf.org/sites/default/files/ending_c hild_marriage.pdf

6. Jain S, and Kurz K. (2007). 'New insights on preventing child marriage: A global analysis of factors and programs', New Delhi, India: International Center for Research on Women. http://lastradainternational.org/lsidocs/icrw_child _marriage_0607.pdf

7. Judith, M., Angeles, N., Heidi, G., John. M. (2016). 'Child Brides, Forced Marriage, and Partner Violence in America: Tip of an Iceberg Revealed', Obstetrics \& Gynecology, 127(4), 706-713. https://doi:10.1097/AOG.0000000000001336

8. Kalamar, A. M., Lee-Rife, S., Hindin, M. J. (2016). 'Interventions to Prevent Child Marriage Among Young People in Low- and Middle-Income Countries: A Systematic
Review of the Published and Gray Literature', J. of Adolescent Health, 59(3), S16-S21. https://doi.org/10.1016/j.jadohealth.2016.06.015

9. Kamal, S.M.M. (2012). 'Childbearing and the use of contraceptive methods among married adolescents in Bangladesh', The European J. of Contraception and Reproductive Health Care, 17(2), 144-154. https://doi:10.3109/13625187.2011.646014

10. Klugman, J., Hanmer, L, Twigg, S., Hasan, T. and McCleary Sills, J. (2014). 'Voice and Agency: Empowering Women and Girls for Shared Prosperity', The World Bank.

https://www.worldbank.org/en/topic/gender/publ ication/voice-and-agency-empowering-womenand-girls-for-shared-prosperity

11. Lule E, Singh S, Chowdhury SA. (2007). 'Fertility regulation behavior and their costs: contraception and unintended pregnancies in Africa and Eastern Europe and Central Asia', Washington: World Bank.

https://openknowledge.worldbank.org/handle/10 986/13783

12. Mahato, S.K. (2016). 'Causes and Consequences of Child Marriage: A Perspective', International J. of Scientific \& Engineering Research, 7(7), 698-702. https://doi:10.14299/ijser.2016.07.002

13. Marriage and the Family, (2009). 'Interactive Population Center.

https://www.unfpa.org/intercenter/cycle/marriag e.html

14. Mathur S, Greene M, Malhotra A. (2003). 'Too young to wed: the lives, rights and health of young married girls', Washington: International Center for Research on Women. https://www.issuelab.org/resources/11421/11421 .pdf

15. Mensch, B., Singh, S., Casterline, J.B. (2005). 'Trends in the timing of first marriage among men and women in the developing world', The Changing Transitions to Adulthood in Developing Countries: Selected Studies, Population Council, 118-171.

https://pdfs.semanticscholar.org/cbe3/5db7abefa d7381f3bb27b63470b41bfbb37d.pdf

16. Mikhail, S. (2010). 'Child marriage and child prostitution: Two forms of sexual exploit- 
tation', Gender and Development, 10(1), 4349. https://doi.org/10.1080/13552070215896

17. Montazeri, S., Gharacheh, M., Nooredin, M., Javad, A.R. and Hassan, E.A. (2016). 'Determinants of Early Marriage from Married Girls' Perspectives in Iranian Setting: A Qualitative Study', J. of Environmental and Public Health, 2016,1-8. https://dx.doi.org/10.1155/2016/8615929

18. Mukherjee, S. (2006). 'Using Legislative Assembly for Social Reform: the Sarda Act of 1929', South Asia Research, 26(3), 219-233. https://doi.org/10.1177/0262728006071514

19. Nour, N.M. (2009). 'Child Marriage: A Silent Health and Human Rights Issue', Reviews in Obstetrics \& Gynecology, 2(1), 51-56. http://europepmc.org/article/med/19399295

20. Save the Children, (2004). 'State of the World's Mothers 2004', Westport, CT: Save the Children.

https://www.savethechildren.org/content/dam/us a/reports/advocacy/sowm/sowm-2015.pdf

21. Senderowitz, J. (1995). 'Adolescent Health: Reassessing the Passage to Adulthood', World Bank Discussion Paper no. 272, Washington DC.

https://books.google.com.bd/books/about/Adoles cent_Health.html?id=4jck3Cd_gvEC\&redir_esc $=\mathrm{y}$

22. UNFPA (2007). 'Giving Girls Today and Tomorrow: Breaking the Cycle of Adolescent Pregnancy', United Nations Population Fund, 2007. https://www.unfpa.org

23. UNICEF (2019). 'UNICEF Data: Monitoring the situation of children and women. https://data.unicef.org/topic/child-protection/ child-marriage/
24. UNICEF (2005). 'Early marriage: a harmful traditional practice', New York. https://www.unicef.org/publications/index_2602 $\underline{4 . h t m l}$

25. UNICEF (2006). 'Child Marriage: Child Protection Information Sheet', New York, NY: UNICEF.

https://www.unicef.org/publications/files/Child Protection_Information Sheets.pdf

26. UNICEF (2001). 'Early Marriage: Child Spouses'. UNICEF Innocenti Research Centre. Florence, Italy. https://www.unicef-irc.org/publications/291early-marriage-child-spouses.html

27. UNICEF (2005). 'Early Marriage: A Harmful Traditional Practice: A Statistical Exploration', New York, NY. UNICEF (2005). Early Marriage: A Harmful Traditional Practice: A Statistical Exploration. New York, NY. https://www.unicef.org/publications/index_2602 $\underline{4 . h t m l}$

28. UN CEDAW, (1994). 'CEDAW General Recommendation No. 21: Equality in Marriage and Family Relations.

http://www.refworld.org/docid/48abd52c0.html

29. UN Human Rights Council, (2014). '27th session of the Human Rights Council (8 to 26 September, 2014) Resolutions, decisions, and President's statements.

https://www.ohchr.org/EN/HRBodies/HRC/Reg ularSessions/Session27/Pages/ResDecStat.aspx

30. Yasmin T., and Husna CA. (2020). Familial support as a determinant of women career development: a qualitative study, Asian J. Soc. Sci. Leg. Stud., 2(4), 76-87. https://doi.org/10.34104/ajssls.020.076087

Citation: Salam S., and Aktar B. (2020). Child marriage in rural Bangladesh and its consequences on reproductive and maternal health: an empirical study, Eur. J. Med. Health Sci., 2(4), 74-85. https://doi.org/10.34104/ejmhs.020.074085 C) (9) 